\title{
PENERAPAN TEORI DIFUSI INOVASI DALAM PENGUATAN KAPASITAS KELOMPOK TANI
}

\section{THE IMPLEMENTATION OF DIFFUSION OF INNOVATION THEORY ON FARMER'S GROUP CAPACITY BUILDING}

\author{
Surachman Suwardi \\ Politeknik Pembangunan Pertanian Bogor \\ Email: surachman_srh@yahoo.com
}

\begin{abstract}
ABSTRAK
Tujuan penulisan adalah untuk mengetahui penerapan teori difusi inovasi dalam penguatan kapasitas kelompok tani. Sedangkan objek penulisan adalah rekonstruksi teori-teori perubahan sistem sosial, komunikasi, dan difusi inovasi, yang berimplikasi dalam pemberdayaan masyarakat, khususnya dalam penguatan kapasitas kelompok menuju dinamika kelompk tani. Metode penelitian adalah kajian pustaka yang dilakukan selama 1 (satu) bulan, yaitu pada bulan Oktober 2018. Hasil analisis disimpulkan bahwa implikasi perkembangan penerapan difusi inovasi dalam pemberdayaan petani, khususnya dalam mengembangkan dinamika kelompok tani adalah perlunya pengembangan strategi penguatan kelompok dan pola penguatan kapasitas kelompok secara sistemik dan berkelanjutan. Pengembangan strategi dan pola penguatan kapasitas kelompok tersebut didasarkan adanya perubahan lingkungan strategis, terutama adanya perubahan kelembagaan penyuluhan. Lahirnya Undang-Undang Perlindungan dan Pemberdayaan Petani menjadi peluang yang baik dalam mendukung pelaksanaan pemberdayaan petani. Aspek yang dikembangkan meliputi tujuan berkelompok, modul pembelajaran berbasis ELC (Experienching Learning Cycle), pendampingan, home base penyuluhan, dan pengembangan kelembagaan usaha.
\end{abstract}

Kata kunci : difusi inovasi, penguatan kapasitas kelompok tani, dinamika kelompok tani

\begin{abstract}
The object of this research to know implementation diffusion of innovation theory on group capacity building. The research object was re-oriented of social system, communication and diffusion of innovation theories that have impact to the empowerment, focus on group capacity building to develop dynamic of farmers'group. The research method was literature riview carried out during a month on October 2018. The results of this reseacrh indicated that strategic and design of capacity building are need development refer to changes of government policy. The polcies are agricultural extension institution. Promulgated farmer empowerment and protection regulation are a good opportunities to support farmer empowerment program. Reorientation aspects are group promotion goals, modul package focus on ELC (Experienching Learning Cycle), field guidance, home base of extension officers, and farm reorganization toward economic scale
\end{abstract}

Keywords : diffusion of innovation, farmer capacity building, dynamic of farmers' group, Experienching Learning Cycle (ELC) 


\section{PENDAHULUAN}

Dampak negatif dari pembangunan adalah terjadinya perubahan-perubahan struktural kehidupan masyarakat. Menurut Paulus Wiratomo (2005) ada tiga perubahan, pertama kekerasan, kedua kemiskinan dan ketiga kehancuran lingkungan. Kemiskinan menggambarkan rendahnya kualitas sumber daya manusia. Jumlah penduduk yang besar tanpa kualitas sumber daya manusia yang memadai akan menjadi beban pembangunan. Untuk mengurangi masalah kemiskinan ini pemerintah terus berupaya mengatasinya melalui program pemberdayaan masyarakat.

Berbagai program telah dilaksanakan oleh pemerintah, seperti Program Pendukung Desa Tertinggal (P2DT), Program Pengembangan Kecamatan (PPK), Program Penanggulangan Kemiskinan Perkotaan (P2KP), Program Makanan Tambahan Anak Sekolah (PMT-AS), Dana Bantuan Operasional Kecamatan, Program Penyediaan Prasarana Dasar Pemukiman (Kawasan Kumuh, Perkotaan dan Pemukiman Nelayan), Program Peningkatan Pendapatan Petani/Nelayan Kecil (P4K), Bantuan Kredit Usaha Tani, Bantuan Sarana Produksi dan Bantuan Modal Usaha, Program Jaring Pengaman Sosial (JPS) yang terdiri dari Program Pemberdayaan Daerah dalam Mengatasi Dampak Krisis Ekonomi (PDM-DKE), Operasi Pasar Khusus (OPK), Beras, Bantuan Beasiswa Sekolah, Program Padat Karya dan Program Prakarsa khusus bagi Penganggur Perempuan.

Secara umum program tersebut belum efektif dapat mengatasi masalah kemiskinan karena kurang memotivasi partisipasi masyarakat serta dilaksanakan secara parsial (sektoral). Sehubungan dengan hal tersebut, maka perlu melakukan peninjauan kembali program-program yang ada, khususnya pada aspek metodologi pemberdayaannya.

Penelitian pada Program P4K sangat strategis karena pertama, program ini berhasil ditumbuhkembangkan, program ini merupakan long term project yang memiliki metodologi pemberdayaan yang telah berhasil melakukan pemberdayaan sosial ekonomi petani/nelayan; ketiga, metodologi yang diterapkan oleh $\mathrm{P} 4 \mathrm{~K}$ berdasarkan hasil kaji tindak dan terbukti berhasil dalam memberdayakan masyarakat miskin. Melalui metoda yang sejenis, India telah berhasil dalam dalam memberdayakan masyarakat miskin. Keempat, Program P4K berlanjut, tidak sebatas proyek sehingga memungkinkan terbentuknya suatu sistem pendidikan masyarakat dalam mencari nafkah.

Hasil-hasil penelitian yang dilakukan oleh V Puhazhendhi ; KJS Satyasai ; MS Kalkur ; dan R Das, RN Barman serta P.K Baruah (Surachman Suwardi, 2009) menyimpulkan bahwa pemberdayaan terhadap masyarakat miskin dengan pembelajaran penguatan kapasitas kelompok akan (1) mampu membangun kegiatan kelompok dalam meningkatkan kesejahteraan anggotanya, (2) berhasil menumbuhkembangkan modal sosial anggota kelompok seperti sifat hemat, tekun dalam berusaha, kebiasaan menabung, menumbuhkan simpan pinjam, rasa percaya diri dan (3) program mampu menumbuhkembangkan kesetaraan jender.

P4K dibentuk oleh Badan Pengembangan SDM Pertanian pada tahun 1979 di enam propinsi dan pada tahun 1999 diperluas menjadi 18 propinsi, yaitu Riau, Bengkulu, Sumatera Selatan, Lampung, Jawa Barat, Jawa Tengah, DI Yogyakarta, Jawa Timur, Bali, Nusa Tenggara Barat, Kalimantan Selatan, Sulawesi Selatan, Sulawesi Tengah, Kalimantan Barat, Sumatera Utara, Sumatera Barat, Nusa Tenggara Timur / Timor Timur dan Aceh, dan tersebar di 122 Kabupaten, 1.043 Kecamatan dan 6.552 Desa.

Pada tahun 2002, P4K telah mampu memfasilitasi 67.802 Kelompok Usaha Kecil (KUK). Selain itu 47.305 KUK telah memiliki tabungan di Bank sebanyak Rp 14,7 milyar dan 24.685 KUK mempunyai tabungan di kelompok senilai Rp 3,8 milyar. Dalam perjalanan sampai pada fase II, 
Propinsi Timor Timur terlepas dari binaan P4K karena telah menjadi negara sendiri, sehingga jangkauan wilayah binaan menurun menjadi 102 Kabupaten, 662 Kecamatan dan 3.857 Desa dengan melibatkan 213 Petugas Pembina tingkat Propinsi, 491 Petugas Pembina tingkat Kabupaten, 2.690 Penyuluh Pertanian (PP) dan Koordinator PP serta 76 Account Officer BRI (AO BRI).

Pada akhir tahun 2005, pengelolaan Program P4K dilanjutkan oleh Permerintah Kabupaten Pelaksana Program P4K. Bupati berperan sebagai penanggungjawab program dibantu oleh seluruh stakeholders seperti dinas/instansi terkait dan BRI/lembaga keuangan lainnya. Program P4K telah memberikan kontribusi dalam pengentasan kemiskinan. Hasil penelitian yang dilakukan Biro Pusat Statistik (2002) menyimpulkan bahwa Program P4K telah berhasil secara efektif dalam mengentaskan sejumlah besar rumah tangga dari kemiskinan. Hal yang sama telah dilakukan oleh Biro Pusat Statistik Propinsi Jawa Barat untuk lokasi Program P4K Propinsi Jawa Barat (Biro Pusat Statistik Propinsi Jawa Barat, 2005).

Beberapa hasil penelitian tentang pemberdayaan pada Program P4K dapat dijadikan rujukan untuk penelusuran perkembangan implikasi teori difusi inovasi pada penguatan kapasitas kelompok tani. Berdasarkan hal tersebut tersebut, maka rumusan dalam penulisan ini adalah sejauh mana implikasi perkembangan penerapan teori difusi inovasi dalam penguatan kapasitas kelompok tani. Maksud penulisan adalah menganalisis dan menjelaskan implikasi perkembangan penerapan teori difusi inovasi dalam penguatan kapasitas kelompok tani. Sedangkan tujuan penulisan adalah untuk mengetahui implikasi perkembangan penerapan teori difusi inovasi dalam penguatan kapasitas kelompok tani.

Tulisan ini diharapkan dapat bermanfaat bagi pengembangan ilmu pengetahuan tentang difusi inovasi serta dapat mempunyai kegunaan praktis yang dapat digunakan dalam memecahkan persoalan yang berkaitan dengan pemberdayaan petani.

100 | Jurnal Agriekstensia No. 17 Vol. 2 Desember 2018

\section{METODE PENELITIAN}

Metode penelitian yang digunakan adalah kajian pustaka yang dilakukan selama 1 (satu) bulan, yaitu pada bulan Oktober 2018. Sedangkan objek penulisan adalah rekonstruksi teori-teori perubahan sistem sosial, komunikasi, dan difusi inovasi, yang berimplikasi dalam pemberdayaan masyarakat, khususnya dalam penguatan kapasitas kelompok menuju dinamika kelompk tani.

\section{HASIL DAN PEMBAHASAN}

\section{Teori Sistem Sosial}

Grand theory yang dipergunakan dalam membahas pemberdayaan adalah adalah Teori Sistem Sosial menurut Talcott Parsons (Johnson, 1986) yang mengkaji sistem sosial dalam dua sudut pandang, yaitu sudut pandang struktural dan fungsional. Dalam sudut pandang struktural para aktor individual yang berinteraksi dapat berkembang menjadi struktur yang lebih luas, yaitu sosial dan budaya. Batas-batas sistem sosial tersebut adalah nilai-nilai atau unsur-unsur yang ada pada sistem sosial tersebut.

Adanya perubahan yang datang dari luar ataupun dari dalam suatu sistem, cenderung sistem itu mempertahankan stabilitasnya melalui empat fungsi yang memaksa, yaitu adaptasi, pencapaian tujuan, integrasi dan pemeliharaan pola yang tersembunyi. Hal ini mengandung pengertian bahwa secara fungsional setiap sistem harus mampu mengelola keempat fungsi tersebut.

Parsons mengistilahkan empat fungsi tersebut sebagai Kerangka AGIL. Pada dasarnya kerangka ini menunjukkan empat prasyarat fungsional yang harus dipenuhi oleh suatu sistem sosial. Kerangka tersebut terdiri dari komponen A, G, I dan L. A singkatan dari Adaptation, $\mathrm{G}$ singkatan dari Goal attainment, I singkatan dari Intergration dan $\mathrm{L}$ singkatan dari Latent pattern maintenance.

Rusidi (1990) mempertegas teori 
sistem sosial yang dipelopori oleh Parsons dengan menghubungkan kerangka AGIL ke dalam struktur dan fungsi sistem sosial. Keterkaitan kerangka AGIL tersebut merupakan strategi analisa fungsional yang dapat diterapkan pada sistem sosial tingkat mikro, mezzo atau makro. Kerangka tersebut menunjukkan pada kebutuhan setiap sistem sosial untuk memenuhi persyaratan fungsional.

Berfungsinya struktur status-status tersebut merupakan seperangkat peranan yang saling mempengaruhi satu sama lain. Dengan demikian struktur sosial dan fungsi sosial berhubungan erat dan saling mempengaruhi. Apabila struktur dan fungsi sosial tersebut berubah, maka akan terjadi perubahan sosial. Melalui pemberdayaan masyarakat diharapkan perubahan tersebut ke arah yang bermanfaat.

\section{Teori Komunikasi}

Middle rank theory berdasarkan tindakan komunikasi dalam sistem pemberdayaan terhadap petani yang berakibat pada perubahan sosial. Rogers dan Shoemaker (1986) dan Roger dan Adhikarya (1978) membahas perubahan sosial dari Teori Komunikasi, yaitu dari aspek difusi inovasi yang disempurnakan, yaitu pendekatan Model Komunikasi Konvergen.

Terdapat dua jenis perubahan sosial berdasarkan sumber terjadinya perubahan, yaitu pertama perubahan imanen, jika sumber perubahan berasal dari dalam sistem sosial. Kondisi ini terjadi jika anggota sistem sosial menciptakan dan mengembangkan ide baru dengan sedikit atau tanpa pengaruh sama sekali dari pihak luar dan kemudian ide baru itu menyebar ke seluruh sistem sosial. Kedua perubahan kontak, jika sumber ide baru berasal dari luar sistem sosial. Kondisi ini terjadi jika sumber dari luar sistem sosial memperkenalkan ide baru (antar sistem).

Berdasarkan datangnya kebutuhan untuk berubah, perubahan kontak terdiri dari perubahan kontak terarah dan perubahan kontak selektif. Perubahan kontak terarah atau perubahan terencana adalah perubahan 101 | Jurnal Agriekstensia No. 17 Vol. 2 Desember 2018 yang disengaja dengan adanya orang luar atau sebagian anggota sistem yang bertindak sebagai agen pembaharu yang secara intensif berusaha memperkenalkan ide-ide baru tersebut untuk mencapai tujuan yang telah ditentukan oleh lembaga dari luar. Sedangkan perubahan kontak selektif terjadi jika anggota sistem sosial terbuka pada pengaruh dari luar dan menerima atau menolak ide baru dari luar.

Ditinjau dari sudut penerima ide-ide baru, Rogers dan Shoemaker (1986), mengklasifikasikannya ke dalam perubahan individual dan perubahan sistem. Perubahan pada tingkat individu dimana seseorang bertindak sebagai individu dalam sistem sosial yang menerima atau menolak inovasi. Perubahan pada tingkatan ini disebut dengan berbagai macam istilah antara lain, difusi, adopsi, modernisasi, akulturasi, belajar atau sosialisasi atau disebut juga sebagai perubahan mikro. Sedangkan perubahan pada tingkat sistem sosial sering diistilahkan sebagai pembangunan, sosialisasi, integrasi, adaptasi atau disebut juga sebagai perubahan makro.

Memperhatikan konsep-konsep komunikasi konvergen, maka proses pemberdayaan terhadap petani akan lebih efektif menggunakan model konvergen. Melalui sistem penyuluhan dengan pendekatan ini, akan diperoleh kesetaraan peran antara Penyuluh Pertanian sebagai komunikator dengan petani sebagai komuikan atau pembelajar.

\section{Teori Difusi Inovasi}

Kementerian Pertanian yang merupakan salah satu kementerian yang melaksanakan Program Peningkatan Kesejahteraan Petani dan telah berhasil melaksanakan pembelajaran masyarakat yang pendapatannya kurang, namun masih mengalami kendala dalam menumbuhkembangkan kelembagaan Kelompok Petani. Kondisi ini disebabkan kurang lancarnya proses komunikasi antara fasilitator, yaitu Penyuluh Pertanian dan petugas dari instansi terkait dan petani binaannya sehingga tingkat adopsinya pada 
program penguatan kapasitas kelompok belum sesuai harapan. Fenomena-fenomena tersebut dikaji melalui Teori Difusi Inovasi dalam Komunikasi Konvergen sebagai applied theory, Teori Andragogi sebagai supporting theory, serta beberapa hasil penelitian, maka diperoleh hasil bahasan terhadap unsur-unsur yang mempengaruhi adopsi petani kecil pada program penguatan kapasitas kelompok.

\section{Perkembangan Teori Difusi Inovasi}

Penelusuran dan temuan hasil penelitian yang dilakukan oleh para peneliti berfokus pada faktor-faktor yang terkait dengan difusi inovasi adalah sebagai berikut

(a) Rogers dalam Van Den Ban dan Hawkins (1999) telah menelusuri beberapa penelitian yang terkait dengan difusi inovasi. Hasil penelusurannya mengungkapkan beberapa variabel yang berhubungan secara positif dengan indeks adopsi. Variabelvariabel tersebut adalah pendidikan, baca tulis, status sosial yang lebih tinggi, unit ukuran besar, orientasi ekonomi komersial, sikap yang lebih berkenan terhadap kredit, sikap yang lebih berkenan terhadap perubahan, sikap yang lebih berkenan terhadap pendidikan, intelegensia, partisipasi sosial, kosmopolitanisme, kontak dengan agen perubahan, keterbukaan dengan media massa, keterlibatan pada saluran antar pribadi, pencarian informasi yang lebih aktif, pengetahuan tentang inovasi dan pendapat tentang kepemimpinan.

Hasil penelusuran penelitian tersebut dapat dijadikan rujukan dalam menelususi faktor-faktor yang mempengarui tingkat keputusan adopsi inovasi yang terjadi dalam suatu sistem sosial. Tingkat keputusan adopsi akan menyebabkan terjadinya perubahan sosial.

(b) Surachman Suwardi (2005) dalam penelitiannya telah menguji hubungan karakteristik petani kecil dan pengalaman dengan responnya terhadap 102 | Jurnal Agriekstensia No. 17 Vol. 2 Desember 2018
Lembaga Keuangan Mikro (LKM)Program P4K. Penelitian ini menggunakan metode survei terhadap LKM-P4K di Kabupaten Kuningan. Metode analisis menggunakan analisis statistik non parametrik koefisien korelasi jenjang Spearman. Hasil penelitian mengungkapkan bahwa pertama, karakteristik petani kecil yang terdiri dari pengalaman di bidang kredit produksi (simpan pinjam) berhubungan secara nyata dengan responnya terhadap LKM ; dan kedua, karakteristik petani kecil yang terdiri dari tingkat pengetahuan, pendapatan, kepercayaan, kebutuhan, kepuasan dan penyesuaian diri berhubungan nyata dengan pengalaman di bidang kredit produksi (simpan pinjam).

Hasil penelitian tersebut dapat dijadikan rujukan dalam menelusuri faktor-faktor yang mempengarui tingkat keputusan adopsi inovasi yang terjadi dalam suatu sistem sosial. Tingkat keputusan adopsi pada penelitian tersebut dipergunakan pada aplikasi teori respon, dengan kategori responden yang sama, yaitu petani kecil yang dibina oleh Program P4K, serta jenis inovasi yang relatif sama, yaitu inovasi sosial tentang pembelajaran kelompok (KPK dan LKM) yang bertujuan untuk merubah cara pandang petani kecil agar meningkat kesejahteraannya.

Hubungan kausalitas antar variabel yang menjadi penelusuran penulis adalah karakteristik petani kecil yang terdiri dari pengalaman di bidang kredit produksi (simpan pinjam) berhubungan secara nyata dengan responnya terhadap LKM.

(c) Isti Wahyuningsih (2003) dalam penelitiannya telah menguji faktorfaktor yang berpengaruh terhadap partisipasi petani kecil dalam kegiatan penguatan kapasitas kelompok pada KPK Program P4K di Kabupaten Boyolali. Metode penelitian menggunakan survei sedangkan metode analisis statistik menggunakan analisis 
jalur. Hasil penelitian menyimpulkan bahwa faktor-faktor yang mempengaruhi partisipasi petani kecil dalam penguatan kapasitas kelompok adalah wawasan petani, tingkat pendidikan petani, sikap petani, motivasi petani, intensitas penyuluhan kredit P4K dan peran tokoh masyarakat. Hasil penelusuran penelitian tersebut dapat dijadikan rujukan dalam menelususi faktor-faktor yang mempengarui tingkat keputusan adopsi inovasi yang terjadi dalam suatu sistem sosial. Tingkat keputusan adopsi pada penelitian tersebut dijelaskan pada tingkat partisipasi petani kecil dalam program penguatan kapasitas kelompok dengan kategori responden yang sama, yaitu petani kecil yang dibina oleh Program P4K, serta jenis inovasi yang relatif sama, yaitu inovasi sosial tentang pembelajaran kelompok yang bertujuan untuk merubah cara pandang petani kecil dalam meningkatkan kesejahteraannya.

Hubungan kausalitas antar variabel yang menjadi penelusuran penulis adalah tingkat partisipasi petani kecil dalam program penguatan kapasitas kelompok dipengaruhi oleh wawasan petani, tingkat pendidikan petani, sikap petani, motivasi petani, intensitas penyuluhan kredit P4K dan peran tokoh masyarakat.

(d) Henrykus Sihaloho (2004) dalam penelitiannya telah mengkaji faktorfaktor yang berpengaruh terhadap efektivitas pemberdayaan anggota KPK dilihat dari perspektif penguatan kapasitas anggota KPK pada Program P4K di Kabupaten Bogor. Metode penelitian menggunakan metode survei sedangkan metode analisis data menggunakan analisis path. Hasil penelitian mengungkapkan bahwa efektivitas pemberdayaan anggota KPK ditinjau dari perspektif peningkatan kapasitas anggota KPK dipengaruhi oleh lingkungan fisik, kekosmopolitan anggota KPK, kebutuhan berkelompok,

103 | Jurnal Agriekstensia No. 17 Vol. 2 Desember 2018 kekuatan pendampingan dan kemajuan usaha anggota KPK.

Hasil penelusuran penelitian tersebut dapat dijadikan rujukan dalam menelusuri faktor-faktor yang mempengarui tingkat keputusan adopsi inovasi yang terjadi dalam suatu sistem sosial. Tingkat keputusan adopsi pada penelitian tersebut dijelaskan pada tingkat efektifitas pemberdayaan petani kecil ditinjau dari perspektif penguatan kapasitas kelompok dengan kategori responden yang sama, yaitu petani kecil yang dibina oleh Program P4K, serta jenis inovasi yang relatif sama, yaitu inovasi sosial tentang pembelajaran kelompok (KPK) yang bertujuan untuk merubah cara pandang petani kecil dalam meningkatkan kesejahteraannya. Hubungan kausalitas antar variabel yang menjadi penelusuran penulis adalah peningkatan kapasitas petani kecil dipengaruhi oleh lingkungan fisik, kekosmopolitan petani kecil, kebutuhan berkelompok, kekuatan pendampingan dan kemajuan usaha petani kecil.

(e) Surachman Suwardi (2009), melengkapi temuan hasil penelitian sebelumnya; (1) menguji hubungan kausal pengaruh antara karakteristik petani kecil sebagai variabel bebas yang meliputi umur, tingkat pendidikan formal, pengetahuan, luas pemilikan lahan, lamanya menjadi petani kecil, pendapatan, kepercayaan, kepuasan, kebutuhan, penyesuaian diri, kekosmopolitan, partisipasi, sifat wirausaha, kesetaraan jender dan kesejahteraan dengan tingkat adopsi petani kecil dalam program penguatan kapasitas kelompok sebagai variabel antara. Beberapa peneliti sebelumnya baru mengungkap hubungan dan pengaruh sebagian karakteristik adopter dengan tingkat adopsi inovasi. Hubungan kausal dimensi-dimensi pada variabel karakteristik petani kecil dengan tingkat adopsi petani kecil dalam penguatan kapasitas kelompok baru terungkap pengaruh tingkat 
kekosmopolitan, wawasan petani dan tingkat pendidikan petani terhadap penguatan kapasitas kelompok pada situasi kebijakan pelaksanaan penyuluhan yang berbeda; (2) menguji hubungan kausal antara sifat inovasi penguatan kapasitas dengan tingkat adopsi petani kecil dalam penguatan kapasitas kelompok; (3) menguji hubungan kausal pengaruh antara faktor pendukung yang meliputi tipe keputusan inovasi, saluran komunikasi, ciri-ciri sistem sosial, umpan balik dan kepemimpinan ketua KPK yang terdiri dari persyaratan ketua KPK dan hal-hal yang harus dilakukan ketua KPK dengan tingkat adopsi petani kecil dalam penguatan kapasitas kelompok;

(4) menguji hubungan kausal antara kebijakan pemerintah tentang Program P4K dengan tingkat adopsi petani kecil dalam program penguatan kapasitas kelompok. Beberapa penelitian baru mengungkap pengaruh intensitas dan kekuatan pendampingan yang dilakukan oleh penyuluh pertanian terkait dengan pembelajaran di kelompok pada situasi kebijakan pelaksanaan penyuluhan yang berbeda.

\section{Implikasi dalam Pengembangan Penguatan Kapasitas Kelompok Tani}

Dengan mencermati hasil penelusuran dan temuan hasil penelitian yang dilakukan oleh para peneliti yang berfokus pada faktor-faktor yang terkait dengan difusi inovasi, maka implikasi terhadap pemberdayaan petani adalah perbaikan pemberdayaan petani melalui sintesa dari model keberfungsian sosial dari $\mathrm{Du}$ Bois dan Milley dan model pengembangan agribisnis petani kecil dari Bungaran Saragih (Surachman Suwardi, 2009). Relevansi hasil penelitian dengan kondisi saat ini, terutama setelah perubahan kelembagaan penyuluhan akibat lahirnya Undang-Undang Nomor 23 tahun 2014, Peraturan Menteri Pertanian Nomor 03/Permentan/SM.200/1/2018 tentang Pedoman Penyelenggaraan Penyuluhan Pertanian serta tuntutan terhadap perlindungan dan pemberdayaan petani (Undang-Undang Nomor 19 tahun 2013), sebagaimana tertera pada Tabel 1 .

Upaya pengembangan penguatan kapasitas kelompok secara sistemik dan berkelanjutan mengacu kepada pendapat Bungaran Saragih (Surachman Suwardi, 2009) sebagaimana disajikan pada Gambar 2. Alur tersebut menggambarkan pembinaan secara sistemik dengan memperhatikan pengembangan skala usaha, yang meliputi perencanaan, pelaksanaan dan evaluasi. Setiap tahapan tersebut dilaksanakan secara integrasi, yang difasilitasi oleh Pemerintah.

Tabel 1. Pengembangan Strategi Penguatan Kapasitas Kelompok

\begin{tabular}{|c|c|c|c|c|}
\hline No. & Variabel & $\begin{array}{l}\text { Dimensi yang perlu } \\
\text { mendapat perhatian } \\
\text { khusus } \\
\end{array}$ & Strategi & Pengembangan Strategi \\
\hline 1. & $\begin{array}{l}\text { Karakteristik } \\
\text { Petani Kecil }\end{array}$ & $\begin{aligned}- & \text { Umur } \\
- & \text { Pendidikan } \\
& \text { formal } \\
- & \text { Pemilikan lahan } \\
& \text { pertanian }\end{aligned}$ & $\begin{array}{l}\text { - } \text { Menyempurnakan indikator } \\
\text { seleksi calon anggota } \\
\text { kelompok berdasarkan } \\
\text { umur produktif, pendidikan } \\
\text { formal dan kepemilikan } \\
\text { lahan } \\
\text { - Memperbaiki indikator } \\
\text { kemiskinan dengan } \\
\text { mempertimbangkan } \\
\text { keberfungsian sosial }\end{array}$ & $\begin{array}{l}\text { Tujuan berkelompok disesuaikan } \\
\text { dengan kebutuhan anggota dan fasilitasi } \\
\text { program pemerintah }\end{array}$ \\
\hline 2. & $\begin{array}{l}\text { Sifat Inovasi } \\
\text { Pe-nguatan } \\
\text { Kapasitas } \\
\text { Kelompok }\end{array}$ & $\begin{array}{l}\text { - Observabilitas } \\
\text { inovasi }\end{array}$ & $\begin{array}{l}\text { Pengembangan modul } \\
\text { pembela-jaran penguatan } \\
\text { kapasitas kelompok } \\
\text { berdasarkan prinsip ELC } \\
\text { (Experience Learning Cycle) }\end{array}$ & $\begin{array}{l}\text { Optimalisasi pengembangan modul } \\
\text { pembelajaran penguatan kapasitas } \\
\text { kelompok berdasarkan prinsip ELC } \\
\text { (Experience Learning Cycle) }\end{array}$ \\
\hline
\end{tabular}




\begin{tabular}{|c|c|c|c|c|}
\hline No. & Variabel & $\begin{array}{l}\text { Dimensi yang perlu } \\
\text { mendapat perhatian } \\
\text { khusus }\end{array}$ & Strategi & Pengembangan Strategi \\
\hline 3. & $\begin{array}{l}\text { Faktor } \\
\text { Pendukung }\end{array}$ & $\begin{array}{ll}\text { - } & \text { Umpan balik } \\
- & \text { Kepemimpinan } \\
& \text { ketua kelompok }\end{array}$ & $\begin{aligned} &- \text { Membangun komunikasi } \\
& \text { bersama client dalam hal ini } \\
& \text { petani kecil dalam } \\
& \text { mengembangkan inovasi } \\
& \text { - } \\
& \text { Melaksanakan kursus yang } \\
& \text { terkait dengan } \\
& \text { kepemimpinan kelompok }\end{aligned}$ & $\begin{array}{l}\text { Optimasilasi pendampingan, kursus tani } \\
\text { dan magang terkait penerapan } \\
\text { teknologi serta Kepemimpinan } \\
\text { Kelompok }\end{array}$ \\
\hline 4. & $\begin{array}{l}\text { Kebijakan } \\
\text { Pemerintah } \\
\text { tentang } \\
\text { Pembelajaran } \\
\text { Program P4K }\end{array}$ & 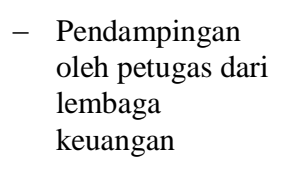 & Integrasi program & $\begin{array}{l}\text { Optimalisasi Penanggung Jawab } \\
\text { Program serta Sinergisme Pelaksanaan } \\
\text { Program Pemberdayaan }\end{array}$ \\
\hline 5. & $\begin{array}{l}\text { Dinamika } \\
\text { Kelompok }\end{array}$ & $\begin{array}{l}\text { - Pemeliharaan dan } \\
\text { pengembangan } \\
\text { kelompok }\end{array}$ & $\begin{array}{l}\text { Mengintensifkan pembinaan } \\
\text { secara sistematis dan } \\
\text { berkelanjutan, melalui } \\
\text { pengembangan agribisnis }\end{array}$ & $\begin{array}{l}\text { Pengembangan Dinamika Kelompok } \\
\text { diarahkan pada Pengembangan Usaha } \\
\text { dan Kelembagaan Petani }\end{array}$ \\
\hline
\end{tabular}

\begin{tabular}{|c|c|c|c|c|}
\hline \multicolumn{5}{|c|}{ Seluruh Stakeholders } \\
\hline \multirow{2}{*}{ 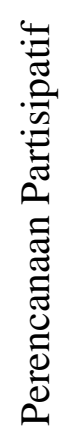 } & $\begin{array}{l}\text { Penumbuhan } \\
\text { kelompok secara } \\
\text { partisipatif }\end{array}$ & $\rightarrow \begin{array}{l}\text { Penguatan kapasitas } \\
\text { kelompok }\end{array}$ & $\begin{array}{l}\text { Pengembangan } \\
\text { Kelompok }\end{array}$ & \multirow[b]{2}{*}{ 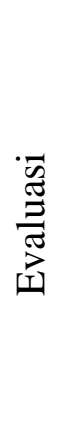 } \\
\hline & 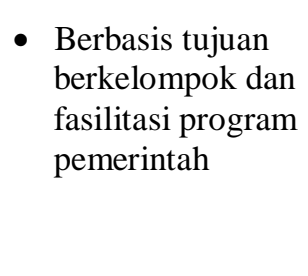 & $\begin{array}{l}\text { - Pembelajaran yang } \\
\text { adaptif melalui } \\
\text { Experience } \\
\text { Learning Cycle }\end{array}$ & $\begin{array}{l}\text { - Farm } \\
\text { Reorganization } \\
\text { - Small-scale } \\
\text { Industrial } \\
\text { Modernization }\end{array}$ & \\
\hline \multicolumn{5}{|c|}{ Service Rationalization } \\
\hline
\end{tabular}

\section{Gambar 2. Pengembangan Pola Penguatan Kapasitas Kelompok secara Sistemik dan Berkelanjutan}

Fase pertama adalah perencanaan secara partisipatif yang melibatkan seluruh stakeholders termasuk client. Proses perencanaan ini dapat difasilitasi melalui Musrenbang (Musyawarah Perencanaan Pembangunan) secara berjenjang. Pada fase kedua dilakukan penumbuhan secara partisipatif dengan melibatkan seluruh stakeholders yang memiliki program sejenis dengan kegiatan yang komplementer. Fase ketiga adalah penguatan kapasitas kelompok yang adaptif dengan menggunakan model ELC (Experiencing Learning Cycle) dan fase keempat adalah farm reorganization melalui penumbuhan pra koperasi, seperti Gabungan KPK, Lembaga Keuangan Mikro 105 | Jurnal Agriekstensia No. 17 Vol. 2 Desember 2018 dan selanjutnya Koperasi. Pada fase ini juga dapat dikembangkan skala usaha yang lebih besar tetapi cepat menghasilkan (quick yielding) yaitu agroindustri.

\section{KESIMPULAN}

Hasil analisis disimpulkan bahwa implikasi perkembangan penerapan difusi inovasi dalam pemberdayaan petani, khususnya dalam mengembangkan dinamika kelompok tani adalah perlunya pengembangan strategi penguatan kelompok dan pola penguatan kapasitas kelompok secara sistemik dan berkelanjutan. Pengembangan strategi dan pola penguatan 
kapasitas kelompok tersebut didasarkan adanya perubahan lingkungan strategis, terutama adanya perubahan kelembagaan penyuluhan. Lahirnya Undang-Undang Perlindungan dan Pemberdayaan Petani menjadi peluang yang baik dalam mendukung pelaksanaan pemberdayaan petani. Aspek yang dikembangkan meliputi tujuan berkelompok, modul pembelajaran berbasis ELC (Experienching Learning Cycle), pendampingan, home base penyuluhan, dan pengembangan kelembagaan usaha.

\section{DAFTAR PUSTAKA}

Badan Pengembangan SDM Pertanian. 2006. P4K Programme Completion Report. Jakarta : Badan Pengembangan SDM Pertanian, Departemen Pertanian.

Biro Pusat Statistik (BPS). 2002. Studi Dampak P4K. BPS Pusat.

Biro Pusat Statistik (BPS) Propinsi Jawa Barat. 2005. Studi Dampak P4K Jawa Barat. BPS Propinsi Jawa Barat.

Hawkin, HS., and AW. Van Den Ban. 1999. Penyuluhan Pertanian. Terjemahan : Agnes Dwina Herdiasti. Kanisius. Yogyakarta.

Johnson, Doyle Paul. 1986. Teori Sosiologi Klasik dan Modern. University of South Florida.

Peraturan Menteri Pertanian Nomor 03/Permentan/SM.200/1/2018 tentang Pedoman Penyelenggaraan Penyuluhan Pertanian.

Rogers, Everett M and Adhikarya, R. 1978. Communication and Inequitable Development : Narrow The Socio Economic Benefit Gap. Media Asia.
Rogers, Everett M. dan Shoemaker, E. Floyd. 1986. Memasyarakatkan Ideide Baru. Surabaya : Usaha Nasional.

Rusidi. 1990. Dinamika Kelompok Tani. Fakultas Pertanian. UNPAD.

Sihaloho, Hendrykus. 2004. Pemberdayaan Pengusaha Kecil melalui Bantuan Kredit dan Pendampingan (Kasus Peserta Proyek P4K di Kabupaten Bogor). Disertasi. IPB.

Suwardi, Surachman. 2005. Respon Petani Kecil terhadap Lembaga Keuangan Mikro/LKM (Suatu Kasus Petani Kecil Anggota Lembaga Keuangan Mikro di Kabupaten Kuningan). Tesis. Program Pascasarjana Universitas Padjadjaran. Bandung.

Suwardi, Surachman. 2009. Faktor-Faktor Yang Mempengaruhi Adopsi Program Penguatan Kapasitas Kelompok Serta Dampaknya Terhadap Dinamika Kelompok Tani (Kasus Program Peningkatan Pendapatan Petani Kecil di Kabupaten Sumedang). Disertasi. Program Pascasarjana Universitas Padjadjaran. Bandung.

Undang-Undang Republik Indonesia Nomor 23 Tahun 2014 tentang Pemerintahan Daerah. Nomor 19 Tahun 2013 tentang Perlindungan dan Pemberdayaan Petani.

Wahyuningsih, Isti. 2003. Partisipasi Petani pada Program Pembinaan Peningkatan Pendapatan Petani Nelayan Kecil (P4K) di Kabupaten Boyolali. Tesis. UGM. 